\title{
Phylogenetic analysis of allexiviruses identified on garlic from Australia
}

\author{
Stephen J. Wylie • Hua Li • Michael G. K. Jones
}

Received: 29 August 2011 / Accepted: 24 November 2011 /Published online: 9 December 2011

(C) Australasian Plant Pathology Society Inc. 2011

\begin{abstract}
Partial genome sequences with identity to members of the genus Allexivirus were described in Australia from Allium sativum L. (garlic). Phylogenetic analysis of coat protein and nucleotide binding protein gene sequences with those of 82 other allexivirus isolates confirmed that the Australian isolates were members of Garlic virus A, Garlic virus $B$, Garlic virus $C$, and Garlic virus D.
\end{abstract}

Keywords Garlic $\cdot$ Virus incursion · Horticulture $\cdot$ Nextgeneration sequencing

International trade and the vegetative means of propagating garlic (Allium sativum L.) favours dissemination of viruses and their accumulation in bulbs. Complex mixtures of viruses of the genera Potyvirus, family Potyviridae; Carlavirus, family Betaflexiviridae; and Allexivirus, family Alphaflexiviridae, occur frequently in Allium sativum L. (garlic) wherever it is grown, causing serious damage to crop yields and quality. The potyviruses onion yellow dwarf virus (OYDV) and leek yellow stripe virus (LYSV), and carlaviruses shallot latent virus (SLV) and garlic common latent virus (GCLV), were described on garlic from Australia (Sward 1990; M. Saqib, personal communication), but only recently were sequences representing allexiviruses identified there (Wylie et al. 2011). Here we compare the partial genome sequences of Australian allexivirus isolates with sequences of those from elsewhere in the world,

S. J. Wylie $(\bowtie) \cdot \mathrm{H}$. Li $\cdot$ M. G. K. Jones

Plant Virology Group,

Western Australian State Agricultural Biotechnology Centre,

School of Biological Sciences and Biotechnology,

Murdoch University,

Perth, WA 6150, Australia

e-mail: s.wylie@murdoch.edu.au speculate on their geographical origin, and discuss possible implications of the incursion into Australia.

Isolation of viral RNA from a single garlic plant purchased from a hardware chain store in Perth, Australia, and determination of nucleotide (nt) sequences using a massively parallel sequencing approach, was described previously (Wylie et al. 2011). Along with other garlic viruses, four distinct nt sequences with identity to allexiviruses were obtained. The partial genomes obtained were from 2,880 $7,708 \mathrm{nts}$ in length, representing approximately $35-92 \%$ of complete genome sequences. Allexivirus isolate sequences used in this study were from Asia, Europe, South America, and Australasia (Table 1). The majority sequences used were from a previous study on isolates from China (Chen et al. 2004), and these represented a region of $~ 723-770$ nucleotides (nt) of the $3^{\prime}$ region of the coat protein $(\mathrm{CP})$ gene and the $5^{\prime}$ region of the nucleotide-binding protein (NTBP). All 86 allexivirus sequences on GenBank were globally aligned using Geneious Pro v5.3 (Drummond et al. 2011) to give an alignment of $723 \mathrm{nt}$. A tree was constructed in MEGA 5 (Tamura et al. 2011) using the Neighbor-Joining method and the Maximum Composite Likelihood substitution model. Data were bootstrapped with 1,000 resamplings to assess the robustness of the lineages in the trees. The homologous region of an isolate of Pepino mosaic virus (family Alphaflexiviridae, genus Potexvirus) was provided as the outgroup.

The allexivirus sequences from Australia grouped with members of four allexivirus species: Garlic virus A, Garlic virus $B$, Garlic virus $C$, and Garlic virus $D$ (Fig. 1). Australian isolate GarVA-Bate1 shared greatest nt identity to Chinese GarVA isolates SS and LZ (85.7\%) from Guangdong and Guangxi, respectively, and least identity (76.8\%) with isolate $\mathrm{CFH}$ from Mongolia. When the available sequence of GarVA-Bate1 (4,363 nt representing the partial replicase module, triple gene block (TGB) 1 and 2, $40 \mathrm{kDa}$ 
Table 1 Allexvirus sequences used

\begin{tabular}{|c|c|c|c|c|c|}
\hline Virus $^{\mathrm{a}}$ & Isolate name (if given) & Location & Length of sequence. Nucleotides & Host species & GenBank accession \\
\hline GarMbFV & - & Argentina & 762 & Allium sativum & X98991 \\
\hline GarMbFV & - & Korea & 723 & A. sativum & AY390254 \\
\hline GarMbMV & GM88 & Japan & 2,518 & A. sativum & D49443 \\
\hline GarVA & - & Japan & $8,660^{\mathrm{c}}$ & A. sativum & AB010300 \\
\hline GarVA & - & Korea & 1,573 & A. sativum & AF478197 \\
\hline GarVA & Bate1 & Australia, $\mathrm{WA}^{\mathrm{b}}$ & 4,363 & A. sativum & JN019812 \\
\hline GarVA & BT & China: Mongolia & 755 & A. sativum & AJ551468 \\
\hline GarVA & $\mathrm{CFH}$ & China: Mongolia & 755 & A. sativum & AJ551467 \\
\hline GarVA & CFL & China: Mongolia & 755 & A. sativum & AJ551469 \\
\hline GarVA & CS1 & China: Hunan & 755 & A. sativum & AJ551470 \\
\hline GarVA & $\mathrm{CS} 2$ & China: Hunan & 755 & A. sativum & AJ551471 \\
\hline GarVA & HK & China: Hainan & 755 & A. sativum & AJ551472 \\
\hline GarVA & LA & China: Anhui & 755 & A. sativum & AJ551473 \\
\hline GarVA & $\mathrm{LZ}$ & China: Guangxi & 755 & A. sativum & AJ551474 \\
\hline GarVA & SS & China: Gungdong & 755 & A. sativum & AJ551475 \\
\hline GarVA & WH & China: Hubei & 755 & A. sativum & AJ551476 \\
\hline GarVA & YY1 & China: Jiangxi & 755 & A. sativum & AJ551477 \\
\hline GarVA & YY2 & China: Jiangxi & 755 & A. sativum & AJ551478 \\
\hline GarVB & - & Japan & 5,077 & A. sativum & AB010301 \\
\hline GarVB & - & Korea & 1,373 & A. sativum & AF543829 \\
\hline GarVB & Bate1 & Australia, $\mathrm{WA}^{\mathrm{b}}$ & 4,923 & A. sativum & JN019813 \\
\hline GarVB & TS1-1 & China: Gansu & 772 & A. sativum & AJ551479 \\
\hline GarVB & TS1-2 & China: Gansu & 772 & A. sativum & AJ551480 \\
\hline GarVB & TS2 & China: Gansu & 772 & A. sativum & AJ551481 \\
\hline GarVB & $\mathrm{YC}$ & China: Ningxia Hui & 772 & A. sativum & AJ551482 \\
\hline GarVC & - & Japan & $8,405^{\mathrm{c}}$ & A. sativum & AB010302 \\
\hline GarVC & - & Argentina & 777 & A. sativum & HM777004 \\
\hline GarVC & Bate1 & Australia, $\mathrm{WA}^{\mathrm{b}}$ & 7,708 & A. sativum & JN019814 \\
\hline GarVC & GarV-6 & Spain & 771 & A. sativum & HQ724845 \\
\hline GarVC & GarV-9 & Spain & 771 & A. sativum & HQ724848 \\
\hline GarVD & - & Japan & 4,497 & A. sativum & AB010303 \\
\hline GarVD & - & Korea & 1,544 & A. sativum & AF519572 \\
\hline GarVD & $\mathrm{AB}$ & China: Sichuan & 755 & A. sativum & AJ551483 \\
\hline GarVD & Bate1 & Australia, $\mathrm{WA}^{\mathrm{b}}$ & 2,280 & A. sativum & JN019815 \\
\hline GarVD & $\mathrm{CFH}$ & China: Mongolia & 755 & A. sativum & AJ551484 \\
\hline GarVD & CFL & China: Mongolia & 755 & A. sativum & AJ551485 \\
\hline GarVD & $\mathrm{DL}$ & China: Yunnan & 755 & A. sativum & AJ551486 \\
\hline GarVD & GarV-1 & Spain & 755 & A. sativum & HQ724840 \\
\hline GarVD & GarV-2 & Spain & 755 & A. sativum & HQ724841 \\
\hline GarVD & GarV-3 & Spain & 755 & A. sativum & HQ724842 \\
\hline GarVD & GarV-4 & Spain & 756 & A. sativum & HQ724843 \\
\hline GarVD & GarV-5 & Spain & 755 & A. sativum & HQ724844 \\
\hline GarVD & GarV-7 & Spain & 755 & A. sativum & HQ724846 \\
\hline GarVD & GarV-8 & Spain & 755 & A. sativum & HQ724847 \\
\hline GarVD & HK & China: Hainan & 755 & A. sativum & AJ551487 \\
\hline GarVD & LA & China: Anhui & 755 & A. sativum & AJ551488 \\
\hline GarVD & $\mathrm{LZ}$ & China: Guangxi & 755 & A. sativum & AJ551489 \\
\hline GarVD & SS & China: Guangdong & 755 & A. sativum & AJ551490 \\
\hline GarVD & $\mathrm{TM}$ & China: Jilin & 755 & A. sativum & AJ551491 \\
\hline GarVD & WH & China: Hubei & 752 & A. sativum & AJ551492 \\
\hline GarVD & $\mathrm{XA}$ & China: Shanxi & 755 & A. sativum & AJ551493 \\
\hline
\end{tabular}


Table 1 (continued)

\begin{tabular}{|c|c|c|c|c|c|}
\hline Virus $^{\mathrm{a}}$ & Isolate name (if given) & Location & Length of sequence. Nucleotides & Host species & GenBank accession \\
\hline GarVD & $\mathrm{XX}$ & China: Henan & 755 & A. sativum & AJ551494 \\
\hline GarVD & YY1 & China: Jiangxi & 755 & A. sativum & AJ551495 \\
\hline GarVD & YY2 & China: Jiangxi & 755 & A. sativum & AJ551496 \\
\hline GarVD & $\mathrm{ZHaZ}$ & China: Fujian & 755 & A. sativum & AJ551497 \\
\hline GarVE & $\mathrm{CFH}$ & China: Mongolia & 755 & A. sativum & AJ551498 \\
\hline GarVE & $\mathrm{CS} 2$ & China: Hunan & 752 & A. sativum & AJ551499 \\
\hline GarVE & TS1 & China: Gansu & 752 & A. sativum & AJ551500 \\
\hline GarVE & TS2 & China: Gansu & 752 & A. sativum & AJ551501 \\
\hline GarVE & $\mathrm{YC}$ & China: Ningxi Hui & 752 & A. sativum & AJ551502 \\
\hline GarVE & $\mathrm{YH}$ & China: Zhejiang & $8,451^{\mathrm{c}}$ & A. sativum & AJ292230 \\
\hline GarVX & 267-GVX1 & Italy & 732 & A. sativum & GQ475424 \\
\hline GarVX & 405-GVX1 & Italy & 732 & A. sativum & GQ475425 \\
\hline GarVX & 407-GVX1 & Italy & 732 & A. sativum & GQ475426 \\
\hline GarVX & $\mathrm{AB} 1$ & China: Sichuan & 767 & A. sativum & AJ551503 \\
\hline GarVX & $\mathrm{AB} 2$ & China: Sichuan & 765 & A. sativum & AJ551504 \\
\hline GarVX & $\mathrm{BD}$ & China: Hebei & 767 & A. sativum & AJ551505 \\
\hline GarVX & BT & China: Mongolia & 766 & A. sativum & AJ551506 \\
\hline GarVX & CQ & China: Sichuan & 767 & A. sativum & AJ551507 \\
\hline GarVX & CS1-1 & China: Hunan & 765 & A. sativum & AJ551508 \\
\hline GarVX & CS1-2 & China: Hunan & 769 & A. sativum & AJ551509 \\
\hline GarVX & CS2-1 & China: Hunan & 769 & A. sativum & AJ551511 \\
\hline GarVX & CS2-1 & China: Hunan & 741 & A. sativum & AJ551510 \\
\hline GarVX & Delhi & India: Delhi & 732 & A. sativum & HQ822272 \\
\hline GarVX & DL & China: Yunnan & 767 & A. sativum & AJ551512 \\
\hline GarVX & GY & China: Guizhou & 767 & A. sativum & AJ551513 \\
\hline GarVX & $\mathrm{JX}$ & China: Shandong & 765 & A. sativum & AJ551514 \\
\hline GarVX & Korea & Korea & $8,106^{\mathrm{c}}$ & A. sativum & U89243 \\
\hline GarVX & LA & China: Anhui & 767 & A. sativum & AJ551515 \\
\hline GarVX & $\mathrm{LZ}$ & China: Guangxi & 765 & A. sativum & AJ551516 \\
\hline GarVX & $\mathrm{NJ}$ & China: Jiangsu & 767 & A. sativum & AJ551517 \\
\hline GarVX & $\mathrm{TM}$ & China: Jilin & 766 & A. sativum & AJ551518 \\
\hline GarVX & $\mathrm{TP}$ & China: Xinjiang & 767 & A. sativum & AJ551519 \\
\hline GarVX & TS2 & China: Gansu & 766 & A. sativum & AJ551521 \\
\hline GarVX & $\mathrm{XA}$ & China: Shanxi & 766 & A. sativum & AJ551522 \\
\hline GarVX & $\mathrm{XX}$ & China: Henan & 767 & A. sativum & AJ551523 \\
\hline GarVX & $\mathrm{YC}$ & China: Ningxia Hui & 766 & A. sativum & AJ551524 \\
\hline GarVX & YH & China: Zhejiang & $8,451^{\mathrm{c}}$ & A. sativum & AJ292229 \\
\hline GarVX & ZhaZ & China: Fujian & 767 & A. sativum & AJ551525 \\
\hline GarVX & ZheZ & China: Henan & 767 & A. sativum & AJ551526 \\
\hline JGV & UK & UK & 2,756 & A. sativum & L38892 \\
\hline PepMV & P22 & Poland & $6,412^{\mathrm{c}}$ & Solanum lycopersicum & HQ650560 \\
\hline ShMbLV & IPO-DLO & Netherlands & 912 & Allium cepa var. aggregatum & EU835196 \\
\hline ShVX & - & Russia & $8,832^{\mathrm{c}}$ & A. cepa var. aggregatum & M97264 \\
\hline ShVX & 1995 & Russia & 2,452 & A. cepa var. aggregatum & L76292 \\
\hline ShVX & Dindugal & India & 1,222 & A. cepa var. aggregatum & GQ268322 \\
\hline ShVX & $\mathrm{NZ}$ & New Zealand & 912 & A. cepa var. aggregatum & EU835197 \\
\hline
\end{tabular}

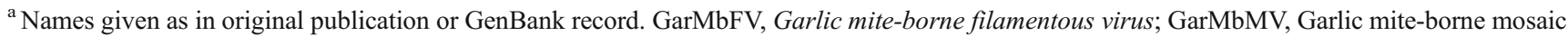
virus; GarVA, Garlic virus A; GarVB, Garlic virus B; GarVC, Garlic virus C; GarVD, Garlic virus D; GarVE, Garlic virus E; GarVX, Garlic virus $X$; JGV, Japanese garlic virus; PepMV, Pepino mosaic virus; ShMbLV, Shallot mite-borne latent virus; ShVX, Shallot virus $X$

${ }^{\mathrm{b}}$ WA, Western Australia

${ }^{\mathrm{c}}$ Listed as complete genome sequence 
Fig. 1 Phylogenetic tree of the nucleotide (nt) sequences representing the $3^{\prime}$ region of the coat protein gene and $5^{\prime}$ region of the nucleotide binding protein gene of 86 allexivirus isolates, including four from Australia (boxed). Species groups are shown. Virus names are shown as in original publication or GenBank record with GenBank accession codes. GarMbFV, Garlic mite-borne filamentous virus; GarMbMV, Garlic mite-borne mosaic virus; GarVA, Garlic virus A; GarVB, Garlic virus B; GarVC, Garlic virus C; GarVD, Garlic virus D; GarVE, Garlic virus E; GarVX, Garlic virus X; JGV, Japanese garlic virus; ShMbLV, Shallot mite-borne latent virus; ShVX, Shallot virus $X$. The sequence of PepMV, (Pepino mosaic virus, family Alphaflexiviridae, genus Potexvirus) is provided as the outgroup. The robustness of the tree was assessed by bootstrapping with 1,000 replications. Bootstrap values $>50 \%$ are shown. The tree was drawn to scale, with evolutionary distance used to infer the branch length in nt substitutions per site

protein gene, CP, NTBP, and 3' untranslated region (3' UTR)) was compared with the complete genome sequence of the Japanese isolate $(8,660 \mathrm{nt}, \mathrm{AB} 010300)$ they shared $83.7 \%$ identity over the entire homologous region, and their CP genes shared $85.1 \%$ identity. Australian isolate GarVBBate1 shared greatest identity $(91.7 \%)$ with the Korean isolate, and least (90.0\%) with isolate TS1-2 from China. When the available sequence of GarVB-Bate1 (4,923 nt, representing the partial replicase module, TGB1, TGB2, $40 \mathrm{kDa}$ protein gene, CP, NTBP, and 3'UTR) was compared with the available sequence of the Japanese isolate $(5,077 \mathrm{nt}$, AB010301), they shared 88.8\% identity over the homologous region, and their CP genes shared identity of $85.1 \%$. Isolates in the GarVB group aligned closely with those of GarVX (Fig. 1) and when the available sequence of isolate GarVB-Bate1 was compared to complete genomes of GarVX isolate YH from China (8,451 nt, AJ292229) and one from Korea (8,106 nt, U89243), it shared 70.9\% and $68.9 \%$ identity with them, respectively. GarVC-Bate1 shared greatest identity $(81.5 \%)$ with the GarVC isolate from Japan, and least (79.5\%) with the isolate from Argentina. When the available sequence of GarVC-Bate1 (7,708 nt, representing the partial replicase module, TGB1, TGB2, $40 \mathrm{kDa}$ protein gene, CP, NTBP, and 3'UTR), representing approximately $92 \%$ of its genome, was compared with the complete genome sequence of the Japanese isolate $(8,405 \mathrm{nt}$, AB010302), they shared only $70.0 \%$ identity, while their complete CP genes shared 77.3\%. Australian isolate GarVD-Bate1 shared greatest identity (93.8\%) with a group of isolates from Spain (GarV-4, GarV-5, GarV-7, GarV-8), and least $(84.9 \%)$ with isolate LA from China. When the available sequence of GarVD-Bate1 (2,880 nt, representing the partial TGB1, TGB2, $40 \mathrm{kDa}$ protein gene, CP, NTBP, and 3'UTR) was compared with the partial genome sequence of the Japanese isolate of GarVD (4,494 nt, AB010303), they shared $87.6 \%$ identity over the homologous region, while their CP genes shared $89.8 \%$ identity.

This study confirmed the taxonomic placement of four allexivirus isolates identified on garlic from Australia as members of GarVA, GarVB, GarVC, and GarVC. Overall,

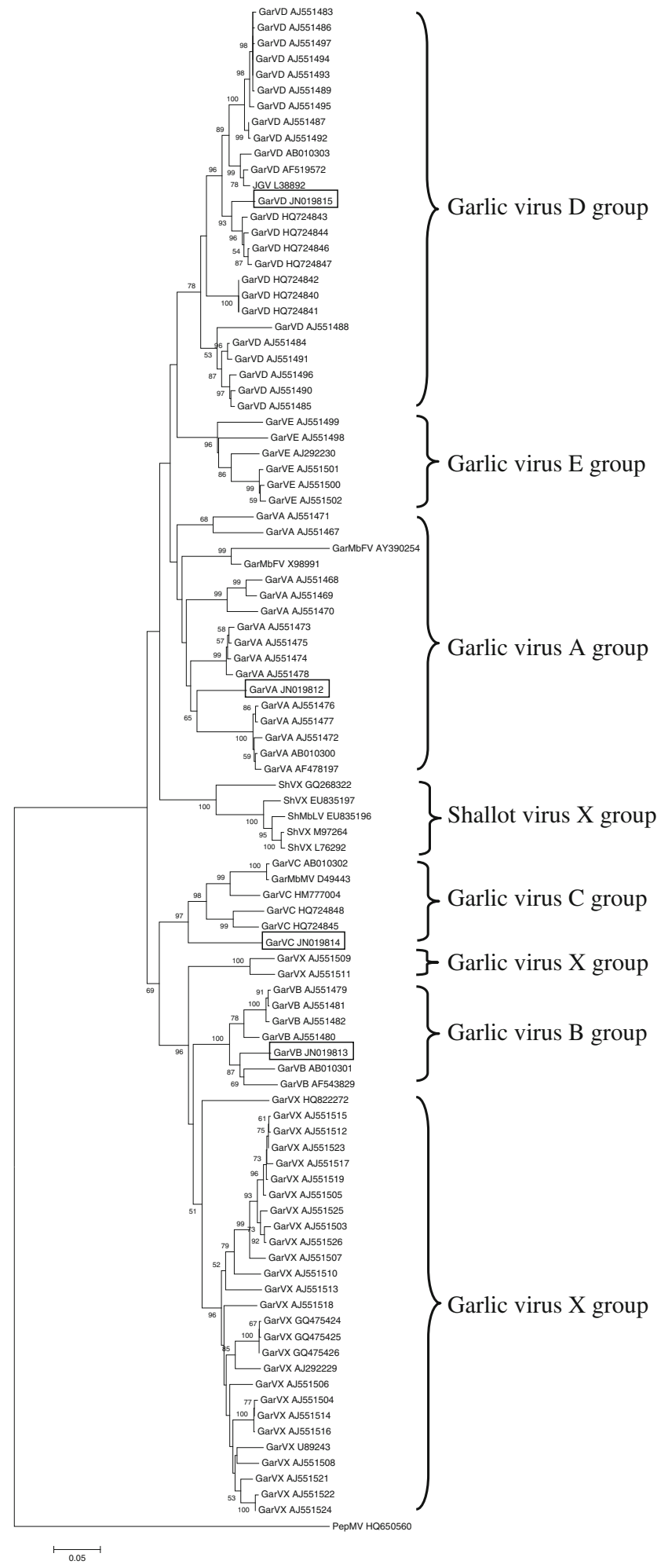

sequences of the partial $\mathrm{CP}$ and NTBP gene region of Australian isolates shared greater than $76.8 \%$ identity with those of known members of the species. This figure is above the species delimitation point of $72 \%$ identity over the complete $\mathrm{CP}$ gene nt sequence proposed by Adams et al. 
(2004). Unfortunately complete CP sequences were not available for most isolates listed on GenBank. When the complete CP gene sequences of the new isolates were compared to complete CP genes from Japanese isolates there was greater than $77 \%$ nt identity in each case, which confirmed identity of each new isolate at the species level.

GarVC-Bate1 was the most divergent isolate with only $70.0 \%$ nt identity over its $90 \%$-complete genome sequence with the complete genome sequence of the isolate from Japan. Surprisingly, the large study of allexiviruses in China failed to detect GarVC in any of the 28 plants from 24 provinces that they tested (Chen et al. 2004), and no GarVC sequences from China are currently available on GenBank (Table 1). Conversely, GarVX was present in most samples tested in the Chinese study (Chen et al. 2004), but was absent in the Australian sample. The presence of GarVC and the absence of GarVX in the single garlic sample tested from Australia suggest that the origin of the new isolates may not be China. Similarly, the genetic distance of the Australian isolates from those from Japan suggests there is not the origin. Unfortunately, the data does not present a clear alternative origin. Despite this evidence, it is probable that China is the ultimate source of the Australian allexivirus isolates. This is because approximately $85 \%$ of fresh garlic consumed in Australia is imported from China (Hickey 2006) as viable bulbs, and the remainder is either imported from the Americas and Spain, or grown locally. Growing imported garlic cloves in home gardens and in nurseries for sale to home gardeners is a common practice that will establish any viruses infecting them in Australia. It is likely therefore that allexiviruses are already established throughout populated Australia and analysis of more garlic plants there should confirm this. The garlic industry in Australia is small, and growers are generally aware of the virus risks associated with growing untested propagules (Sward and Brennan 1994), so it is unlikely that incursion into Australia by allexivirus isolates will have a great economic impact. Allexiviruses are mite-borne and have narrow host ranges, being restricted to alliums. As there are no indigenous members of the Alliaceae in Australia they are unlikely to have an impact on the native flora.

Acknowledgments This study was funded by Australian Research Council Linkage Grant LP110200180 and the Murdoch University Institutes of Sustainable Ecosystems, and Crop and Plant Research.

\section{References}

Adams MJ, Antinow JF, Bar-Joseph M, Brunt AA, Candresse T, Foster GD, Martelli GP, Milne RG, Fauquet CM (2004) The new plant family Flexiviridae and assessment of molecular criteria for species demarcation. Arch Virol 149:1045-1060

Chen J, Zheng H-Y, Antoniw JF, Adams MJ, Chen J-P, Lin L (2004) Detection and classification of allexiviruses from garlic in China. Arch Virol 149:435-445

Drummond AJ, Ashton B, Cheung M, Heled J, Kearse M, Moir R, Stones-Havas S, Thierer T, Wilson A (2011) Geneious v5.5, www.geneious.com

Hickey M (2006) Growing garlic in NSW. Primefacts. Nov 2006. Department of Primary Industries, New South Wales

Sward RJ (1990) Lettuce necrotic yellows rhabdovirus and other viruses infecting garlic. Australas Plant Pathol 19:46-51

Sward RJ, Brennan AP (1994) Diagnosis and control of allium virus diseases in Victoria, Australia. Acta Hort 358:295-298

Tamura K, Peterson D, Peterson N, Stecher G, Nei M, Kumar S (2011) MEGA5: Molecular evolutionary genetics analysis using maximum likelihood, evolutionary distance, and maximum parsimony methods. Mol Biol Evol. doi:10.1093/molbev/msr121

Wylie SJ, Luo H, Li H, Jones MGK (2011) Multiple polyadenylated RNA viruses detected in pooled cultivated and wild plant samples. Arch Virol. doi:10.1007/s00705-011-1166-x 